\title{
MONITORING THE DISTRIBUTION OF CRAYFISH IN ENGLAND AND WALES.
}

\author{
P.J. SIBLEY (1), J.H. BRICKLAND (2), J.A. BYWATER (3)
}

(1) Environment Agency, Midlands Region, Trentside, Scarrington Rd, West Bridgford, NOTTINGHAM, NG2 5FA, United Kingdom.

E-mail : peter.sibley@environment-agency.gov.uk

(2) British Waterways, Fearns Wharf, Neptune St, LEEDS, LS9 8PB, United Kingdom.

(3) Environment Agency, Thames Region, Isis House, Howberry Park, Crowmarsh Gifford, WALLINGFORD, OX10 8BD, United Kingdom.

\begin{abstract}
The distribution of crayfish in England and Wales is described for the period 1997 to 2001 inclusive and is illustrated using a catchment based classification scheme and 10-km square maps. Comparison with previous data from the period 1990 to 1996 shows a decrease in the number of catchments where the native crayfish, Austropotamobius pallipes, is present. Conversely there has been an increase in the distribution of non-native species, notably Pacifastacus leniusculus, which is now more widely distributed than $A$. pallipes (according to presence within $10-\mathrm{km}$ squares of the Ordnance Survey National Grid of England and Wales). The Environment Agency is the main environmental regulator in England and Wales, and plays a key role in gathering crayfish survey data. A co-ordinated programme of monitoring and reporting, ideally involving partner organisations, should be utilised to accurately reflect the changing status of crayfish in these countries. Crayfish survey data is currently recorded on a series of local databases within the Agency, and records are also stored on a national freshwater invertebrate archive used primarily for water quality monitoring purposes. Records generated by other groups and individuals are collated by the Biological Records Centre, with whom the Environment Agency has established links, and the need for a dedicated national database has been expressed by many workers. One area currently under development involves the National Biodiversity Network, a medium for sharing wildlife information via the internet, founded by a consortium of statutory and conservation organisations.
\end{abstract}

Key-words: distribution, Austropotamobius pallipes, Pacifastacus leniusculus, Environment Agency, monitoring, databases. 


\section{CONTRÔLE DE LA DISTRIBUTION DES ÉCREVISSES EN ANGLETERRE ET AU PAYS DE GALLES.}

\section{RÉSUMÉ}

La distribution des écrevisses en Angleterre et au Pays de Galles est décrite pour la période de 1997 à 2001 (inclus) et est illustrée en utilisant un schéma de classification par bassin ainsi que des cartes réalisées par quadrat de $10 \mathrm{~km}^{2}$. La comparaison avec des données antérieures obtenues sur la période de 1990 à 1996 révèle une diminution du nombre de bassins hébergeant l'écrevisse autochtone Austropotamobius pallipes. Inversement, on observe une augmentation des populations d'écrevisses exotiques, en particulier Pacifastacus leniusculus qui est plus largement répandue qu'A. pallipes (d'après la présence notée par quadrat de $10 \mathrm{~km}^{2}$ sur la grille nationale du service topographique de l'Angleterre et du Pays de Galles). L'Agence de l'Environnement est le principal modérateur environnemental en Angleterre et au Pays de Galles et joue un rôle clef pour concentrer les données sur la distribution des écrevisses. Un programme de coordination des contrôles et des rapports, devant impliquer idéalement les organisations partenaires, devrait être utilisé pour décrire avec précision la situation changeante des écrevisses. La distribution des écrevisses est actuellement enregistrée sur une série de données locales au sein de l'Agence et ces données sont aussi stockées dans une archive nationale sur les invertébrés d'eau douce utilisée principalement à des fins de surveillance de la qualité des eaux. Les données obtenues par d'autres groupes et des individus sont regroupées dans le centre de données biologiques - avec qui l'Agence de l'Environnement a établi des liens - et la nécessité d'avoir une base de donnée nationale référencée a été exprimée par beaucoup de personnes impliquées. Un domaine actuellement en développement implique le Réseau National de la Biodiversité, initié par un consortium d'organisations statutaires et de conservation et qui donne le moyen de partager les informations via internet.

Mots-clés : distribution, Austropotamobius pallipes, Pacifastacus leniusculus, Agence de l'Environnement, surveillance, bases de données.

\section{INTRODUCTION}

Austropotamobius pallipes faces an uncertain future in England and Wales, where it is vulnerable to pollution, habitat destruction and competition from introduced crayfish such as $P$. leniusculus. This species is a vector for crayfish plague, a fungal pathogen which can spread rapidly through populations of $A$. pallipes and has caused them to disappear from many parts of Britain (HOLDICH and ROGERS, 1997a; HOLDICH et al., 1999).

Measures geared to the conservation of $A$. pallipes and the management of nonnative crayfish have been written into a number of Biodiversity Action Plans (BAPs) and various Environment Agency strategies and objectives (formerly including Local Environment Agency Plan (LEAP) actions). Such work follows the lead of the UK Action Plan for A. pallipes (THE UK BIODIVERSITY STEERING GROUP, 1995). The key objective of this Action Plan is to " maintain the present distribution of ... (A. pallipes) ", and fundamental to this aim is the requirement for an effective programme of distribution monitoring and reporting.

Distribution monitoring provides the local manager with the information necessary to target and undertake appropriate conservation measures. However, regular national updates are required to monitor changing distribution patterns and to gauge the success of management activities, such as the introduction of licensing requirements (and creation of « no-go » areas) for the keeping of non-native crayfish by government authorities in 
1996. Distribution maps remain an effective method for reporting new data, whether based on point records, $10-\mathrm{km}$ squares or catchment classes. The latter were used by HOLDICH and ROGERS (1997b) in the production of a strategy constructed for the Environment Agency to reflect the most appropriate catchment based management options in relation to resident crayfish populations.

In producing this paper the authors hope to inform and promote the development of a co-ordinated management strategy for the conservation of $A$. pallipes and the control of non-native crayfish.

\section{DISTRIBUTION UPDATE}

\section{0-km square distribution}

A map showing the eight Environment Agency regions (Figure 1) was used as a template for the distribution plots. Records were mapped according to presence within $10-\mathrm{km}$ squares of the Ordnance Survey National Grid for Britain using the following symbols:

- crayfish record

unconfirmed record

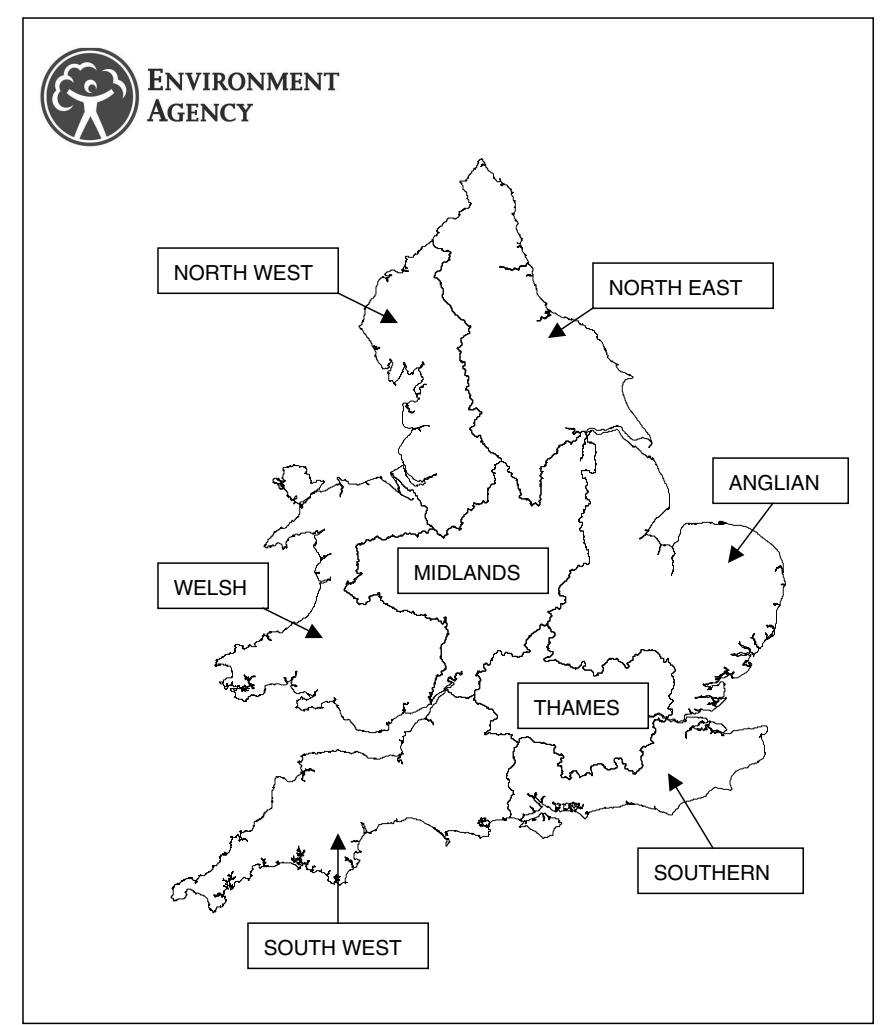

Figure 1

The eight Environment Agency regions of England and Wales.

Figure 1

Les huit Agences de l'Environnement présentes en Angleterre et au Pays de Galles. 
The distribution of $A$. pallipes in England and Wales during the period 1990-1996 inclusive is shown in Figure 2 (see Table I for a breakdown of results). 296 10-km Ordnance Survey squares were reported to be inhabited by $A$. pallipes during this period. The actual distribution was likely to have been somewhat higher since well established populations have subsequently been discovered during targeted survey work, particularly in the North of England. Of the eight Environment Agency regions, North East and Midlands were most densely populated (68 and 65 squares respectively), together accounting for $45 \%$ of occupied $10-\mathrm{km}$ squares across England and Wales during this period. Since 1997 the distribution of $A$. pallipes has declined (Figure 3), falling to 234 10-km squares during 1997-2001 inclusive, a fall of 21\% nationally. North East and Midlands regions were again relatively widely populated, accounting for $48 \%$ of occupied squares during this period (52 and 60 squares respectively).

The distribution of $P$. leniusculus during 1990-1996 is shown in Figure 4. The species was recorded in 169 10-km squares across England and Wales during this period, and was most widely distributed in Thames, Anglian and South West regions (40, 39 and 36 squares respectively). Together these accounted for $68 \%$ of all occupied 10-km squares. Since 1997 the recorded distribution of $P$. leniusculus has increased (Figure 5), with populations found in $24210-\mathrm{km}$ squares during the period 1997-2001, a rise of $43 \%$ nationally. Populations in Thames, Anglian and South West regions were again most widely distributed (53, 54 and 40 squares respectively) accounting for $61 \%$ of the total number of occupied $10-\mathrm{km}$ squares. North East and Midlands regions were host to significant increases in the distribution of $P$. leniusculus during this period, the number of populated $10-\mathrm{km}$ squares rising from 7 to 14 and 16 to 34 respectively.

Table I

Regional distribution (by 10-km square) of Austropotamobius pallipes and Pacifastacus leniusculus (in bold) in England and Wales, based on the periods 1990-1996 and 1997-2001 inclusive.

\section{Table I}

Distribution régionale (par quadrat de $10 \mathrm{~km}^{2}$ ) d'Austropotamobius pallipes et de Pacifastacus leniusculus (en gras) en Angleterre et au Pays de Galles à partir des données récoltées pendant les périodes de 1990 à 1996 et de 1997 à 2001 (inclus).

\begin{tabular}{|c|c|c|c|c|c|c|}
\hline & \multicolumn{2}{|c|}{ (a) 1990-1996 } & \multicolumn{2}{|c|}{ (b) $1997-2001$} & \multicolumn{2}{|c|}{ Net change ( $a$ to $b$ ) } \\
\hline REGION & $\begin{array}{c}\text { No. } 10-\mathrm{km} \\
\text { squares }\end{array}$ & $\begin{array}{l}\% \text { of } \\
\text { total }\end{array}$ & $\begin{array}{c}\text { No. } 10-\mathrm{km} \\
\text { squares }\end{array}$ & $\begin{array}{l}\% \text { of } \\
\text { total }\end{array}$ & $\begin{array}{l}\text { No. } 10-\mathrm{km} \\
\text { squares }\end{array}$ & $\begin{array}{c}\text { overall } \\
(\%)\end{array}$ \\
\hline \multirow{2}{*}{ ANGLIAN } & 38 & 12.8 & 23 & 9.8 & -15 & -39.5 \\
\hline & 39 & 23.1 & 54 & 22.3 & +15 & +38.5 \\
\hline \multirow{2}{*}{ MIDLANDS } & 65 & 22 & 60 & 25.6 & -5 & -7.7 \\
\hline & 16 & 9.5 & 34 & 14 & +18 & +112.5 \\
\hline \multirow{2}{*}{ NORTH EAST } & 68 & 23 & 52 & 22.2 & -16 & -23.5 \\
\hline & 7 & 4.1 & 14 & 5.8 & +7 & +100 \\
\hline \multirow{2}{*}{ NORTH WEST } & 32 & 10.8 & 23 & 9.8 & -9 & -28.1 \\
\hline & 5 & 3 & 9 & 3.7 & +4 & +80 \\
\hline \multirow{2}{*}{ SOUTHERN } & 9 & 3 & 9 & 3.8 & 0 & 0 \\
\hline & 22 & 13 & 31 & 12.8 & +9 & +40.1 \\
\hline \multirow{2}{*}{ SOUTH WEST } & 24 & 8.1 & 17 & 7.3 & -7 & -29.2 \\
\hline & 40 & 23.7 & 53 & 21.9 & +13 & +32.5 \\
\hline \multirow{2}{*}{ THAMES } & 34 & 11.5 & 31 & 13.2 & -3 & -8.8 \\
\hline & 40 & 23.7 & 53 & 21.9 & +13 & +32.5 \\
\hline \multirow{2}{*}{ WELSH } & 26 & 8.8 & 19 & 8.1 & -7 & -26.9 \\
\hline & 4 & 2.4 & 7 & 2.9 & +3 & +75 \\
\hline \multirow{2}{*}{ TOTALS } & 296 & 100 & 234 & 100 & -60 & -20.3 \\
\hline & 169 & 100 & 242 & 100 & +73 & +43.2 \\
\hline
\end{tabular}




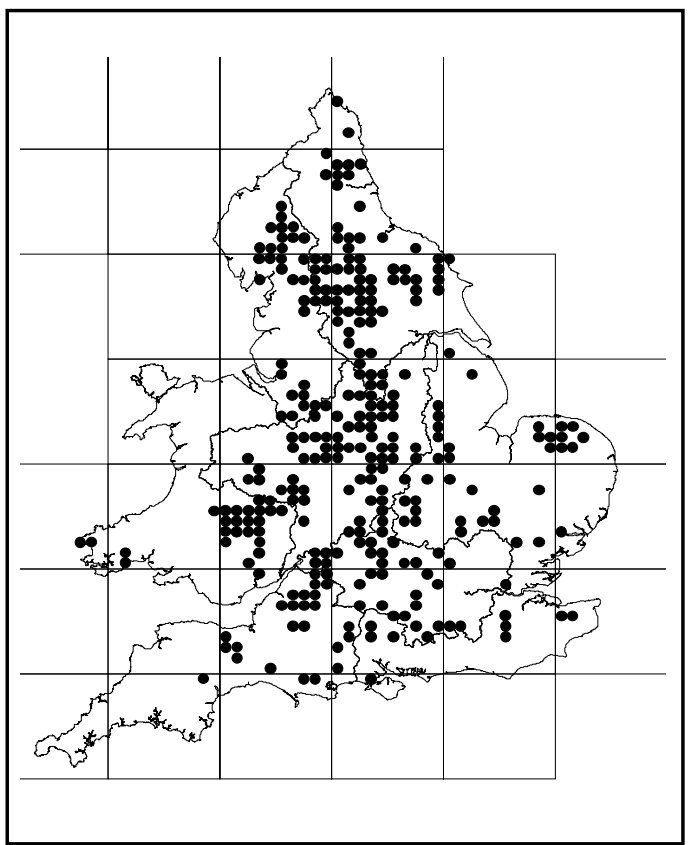

Figure 2

Distribution (by 10-km square) of Austropotamobius pallipes in England and Wales based on records for 1990-1996 inclusive.

Figure 2

Distribution de Austropotamobius pallipes (par quadrat de $10 \mathrm{~km}^{2}$ ) en Angleterre et au Pays de Galles à partir des données récoltées de 1990 à 1996 inclus.

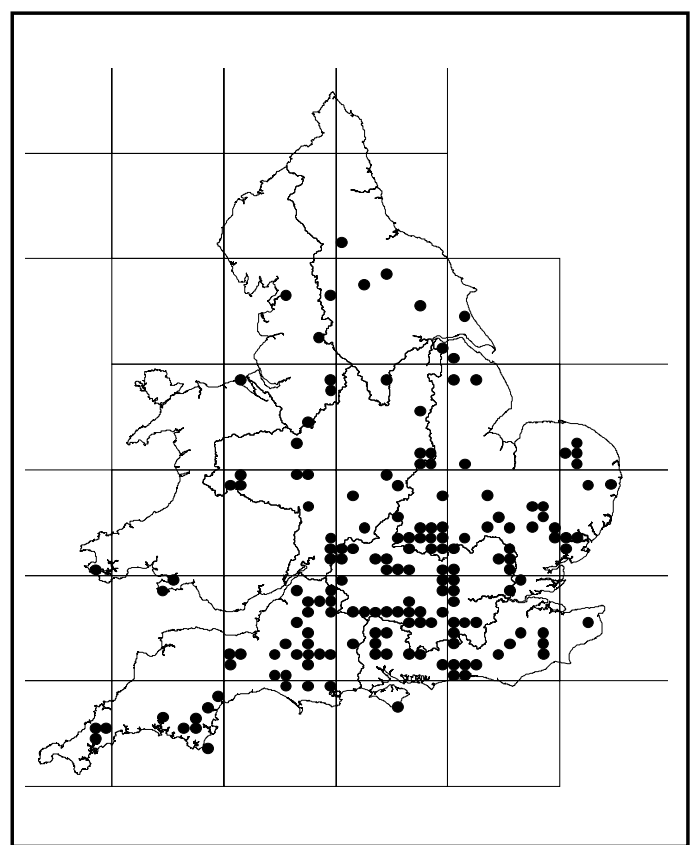

Figure 4

Distribution (by 10-km square) of Pacifastacus leniusculus in England and Wales based on records for 1990-1996 inclusive.

Figure 4

Distribution de Pacifastacus leniusculus (par quadrat de $10 \mathrm{~km}^{2}$ ) en Angleterre et au Pays de Galles à partir des données récoltées de 1990 à 1996 inclus.

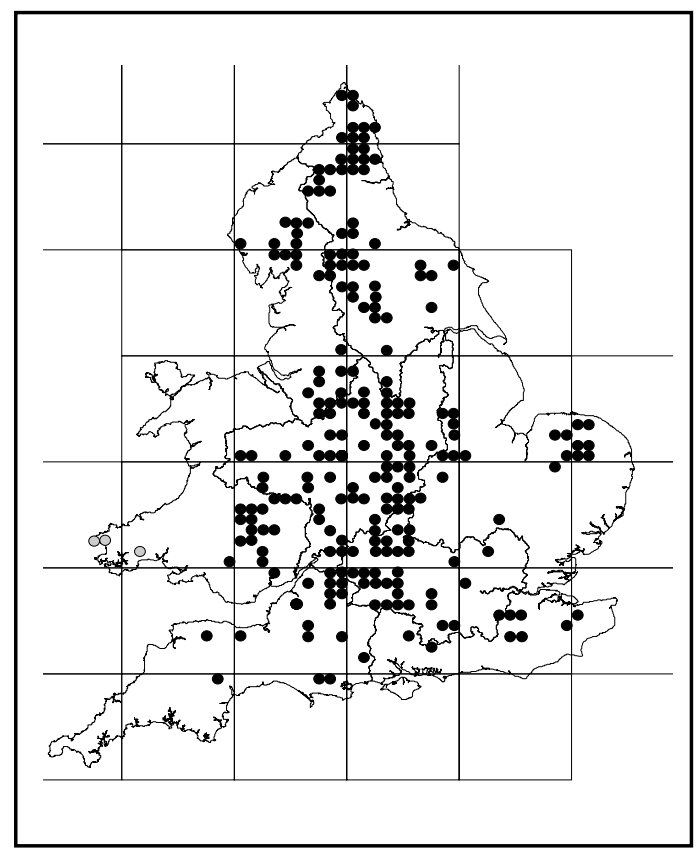

Figure 3

Distribution (by 10-km square) of Austropotamobius pallipes in England and Wales based on records for 1997-2001 inclusive.

Figure 3

Distribution de Austropotamobius pallipes (par quadrat de $10 \mathrm{~km}^{2}$ ) en Angleterre et au Pays de Galles à partir des données récoltées de 1997 à 2001 inclus.

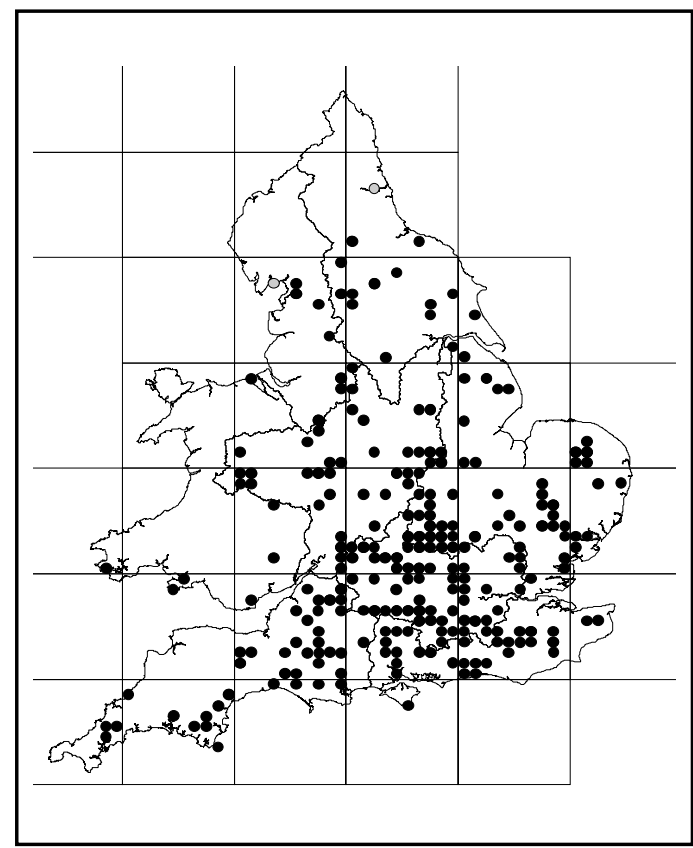

Figure 5

Distribution (by 10-km square) of Pacifastacus leniusculus in England and Wales based on records for 1997-2001 inclusive.

Figure 5

Distribution de Pacifastacus leniusculus (par quadrat de $10 \mathrm{~km}^{2}$ ) en Angleterre et au Pays de Galles à partir des données récoltées de 1997 à 2001 inclus. 


\section{Catchment classification}

Designated catchment areas, each of which encompass one or more river system, were classified according to the relative abundance of native and non-native crayfish present during the periods 1990-1996 (Figure 6) and 1997-2001 (Figure 7) inclusive. During both periods crayfish were recorded in most catchments of England and Wales, although there was (and is) great variation in the density of records and crayfish populations, some catchments yielding hundreds of records and others just one or two. A proportion of catchments may therefore be classified as a result of relatively small populations which were, and may still be, confined to small geographical areas (e.g. stillwaters or restricted reaches of rivers or streams). Since all $A$. pallipes populations have some conservation value the authors feel this approach is useful in highlighting priority catchments in need of management action.

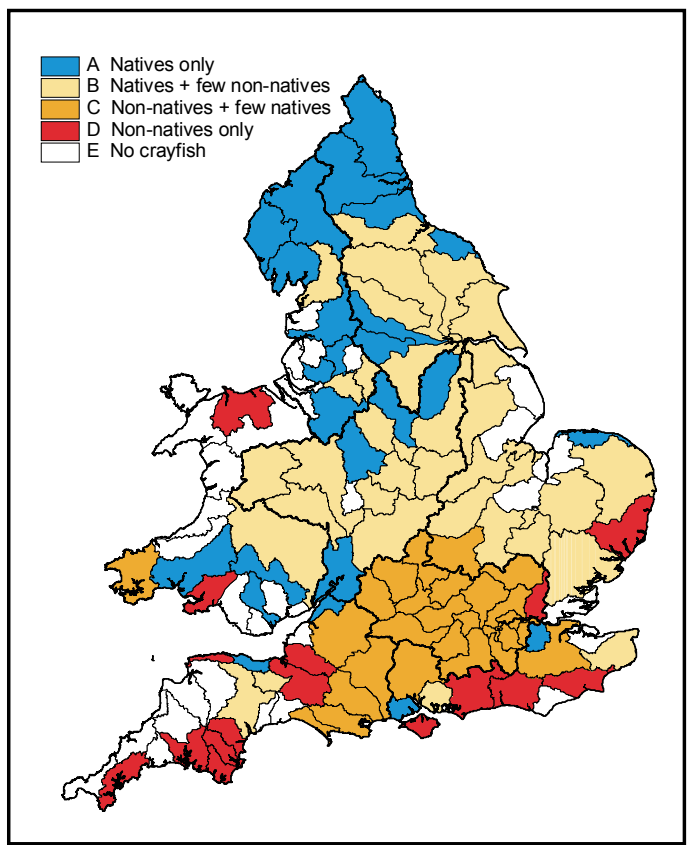

Figure 6

Crayfish distribution in England and Wales according to former LEAP catchment area classification, 1990-1996 inclusive (modified from HOLDICH and ROGERS, 1997b).

Figure 6

Distribution des écrevisses en Angleterre et au Pays de Galles selon la classification par bassin élaborée par l'Agence Locale de l'Environnement, pour la période de 1990 à 1996 (inclus) (modifié par HOLDICH et ROGERS, 1997b).

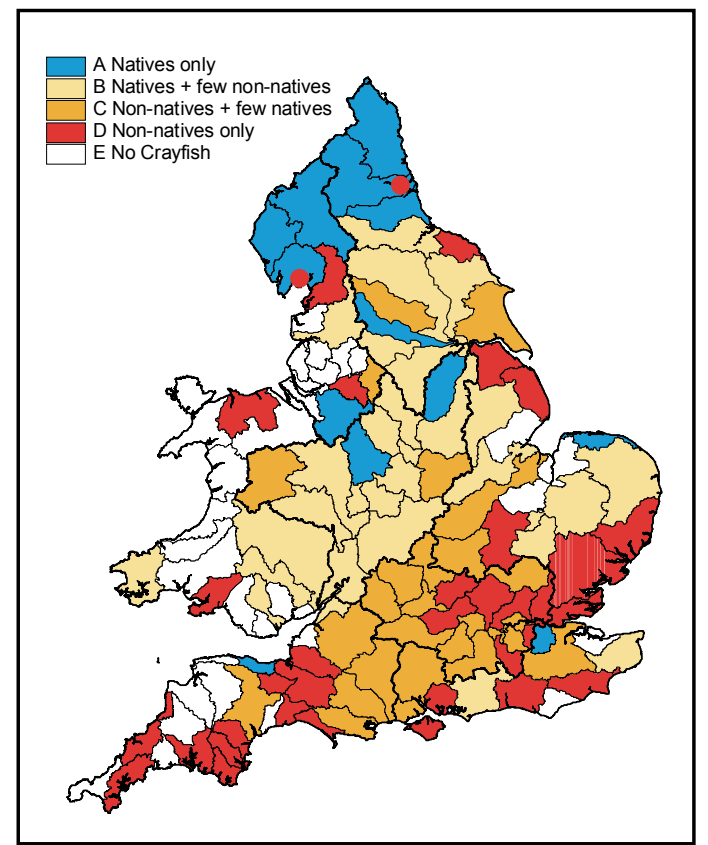

Figure 7

Crayfish distribution in England and Wales according to former LEAP catchment area classification, 1997-2001 inclusive.

Figure 7

Distribution des écrevisses en Angleterre et au Pays de Galles selon la classification par bassin élaborée par l'Agence Locale de l'Environnement, pour la période de 1997 à 2001 (inclus).

Since 1997 there has been a significant change in catchment status resulting in the re-classification of many of the 131 catchment areas. Net changes are summarised as follows (see catchment category descriptions below):

Category A (Natives only)

Category B (Natives and few non-natives)

Category $C$ (Non-natives and few natives)

Category $\mathrm{D}$ (Non-natives only)

Category E (No crayfish)
1990-1996

24

32

27

16

32
1997-2001 Net change

$13-11$

$27 \quad-5$

$27 \quad 0$

$33+17$

$31-1$ 
The updated map for 1997-2001 inclusive (Figure 7) shows an overall decline in the number of catchments containing populations of $A$. pallipes only, with 11 fewer than in the previous period from 1990-1996 (Figure 6). By contrast, there was an increase in the overall number of catchments where non-native crayfish only were present, with 17 more in 1997-2001 than were recorded in 1990-1996. In addition to the widespread P. leniusculus the following non-native species were occasionally recorded: Astacus astacus, Astacus Leptodactylus, Orconectes limosus and Procambarus clarkii (P. leniusculus was also reported from two catchments in the north of England currently classed as category $A$ (P. STEBBING and B. INGERSENT, pers. comm.), these reports are being investigated and may lead to the re-classification of these catchments to category $B$ ).

\section{Explanatory note on the maps}

The distribution and catchment updates are based on records provided by Environment Agency scientists and on data from the Agency's national freshwater invertebrate database (B4W). The authors contacted one or more person from each of the Environment Agencys 26 operational areas across England and Wales, receiving information from all eight regions, including recent crayfish records from 23 out of 26 areas. The majority of these records were collected during field surveys undertaken by Agency workers or licenced contractors using accepted survey techniques (e.g. kick sampling, hand searching, night survey and trapping). Records collected in this way and recorded by a designated Agency scientist were deemed to be genuine and are reported here as confirmed records.

\section{Catchment category descriptions (Figures 6 and 7)}

Using the information described above (and that gathered previously by $\mathrm{HOLDICH}$ and ROGERS (1997b)) each of the catchment areas shown in Figures 6 and 7 were allocated one of the following categories:
A (BLUE)
Catchments with widespread or locally abundant populations of native crayfish. Non-native crayfish absent.
B (PALE ORANGE) Catchments with a limited spread of non-native crayfish (including crayfish farms) and widespread or locally abundant populations of native crayfish.
C (DARK ORANGE) Catchments with widespread or locally abundant populations of non-native crayfish (including crayfish farms) and a limited spread of native crayfish.
D (RED)
Catchments with populations of non-native crayfish (including crayfish farms). Native crayfish absent.
E (WHITE) No confirmed crayfish records.

The unconfirmed reports of $P$. leniusculus from two category A catchments in the north of England are identified as solid red circles in Figure 7. 


\section{SURVEY AND MONITORING}

There is a clear need for the maintenance of high quality crayfish distribution data, for both native and non-native species. The amount of data collected has increased steadily over the last 30 years for the following reasons:

- the farming of exotic species, primarily $P$. leniusculus began in Britain in the mid1970 's resulting in inevitable escapes from farms and the establishment of wild populations

- ecological issues in general have had a higher profile, resulting in an increased interest and a desire to understand what is happening in our environment

- the formation of the National Rivers Authority in 1989, which became a major component of the Environment Agency (formed in 1996), created an environmental « watch-dog » with clear conservation responsibilities focussed on the aquatic environment

- after the Earth Summit in 1992 the UK Government published an Action Plan for " priority species and habitats » which included $A$. pallipes (THE UK BIODIVERSITY STEERING GROUP, 1995). This has served to raise the profile of the native crayfish and set out actions for Government organisations to help conserve this species.

Many organisations including English Nature, British Waterways, Wildlife Trusts, Local Authorities and Universities collect crayfish data but the majority has been collected by, or on behalf of, the Environment Agency through survey work. Whilst there has been a general increase in crayfish survey work, the amount can vary considerably between Environment Agency regions and will often differ at area level within a region. The majority of Environment Agency survey work is co-ordinated at area level and therefore the amount that is undertaken will depend on the priorities and the budget for each area. In addition, personal interests of staff members can influence the amount of survey work since an " interested » staff member is more likely to raise the profile of the crayfish, fight for funds and incorporate survey work into their job.

It is important to note the difference between surveying and monitoring. A survey is usually a one-off visit to a site for a specific reason; this can give valuable data but is limited in terms of providing information about overall trends and changes in distribution over time. Only when a survey is repeated does it become monitoring. Some monitoring is undertaken within the Environment Agency, particularly to assess the extent and spread of populations of non-native species, e.g. Moss Brook in North Derbyshire (BRICKLAND, unpubl. data) and Gaddesby Brook in Leicestershire (SIBLEY, 2001). This monitoring is generally catchment based and, for the same reasons as the survey work, it is conducted at area level.

As the situation regarding the spread of alien crayfish in Britain becomes increasingly serious, the need for a better structured approach to monitoring becomes more pressing. Updating the $10-\mathrm{km}$ grid square or catchment category based maps as described earlier stimulates discussion and is an effective way of highlighting change in national distribution patterns. However, this approach does not give the ecologist enough detailed information about local crayfish populations to make practical management decisions. To assess the conservation value of a specific geographical area it is important for the local manager to know the nature and extent of individual populations. Such information should be reported at a greater level of detail than is possible using only $10-\mathrm{km}$ grid squares, where many or few sub-populations may exist within a single square. An issue which could be overlooked using 10-km grid squares or catchment based maps would be the fragmentation of populations resulting in smaller isolated groups at greater risk of extinction, and with a loss of genetic variation in the population as a whole. GRANDJEAN et al. (1997) working with $A$. pallipes have suggested that there was little 
genetic difference between several British crayfish populations. However, EDSMAN et al. (2002) working with $A$. astacus found that isolated populations which are geographically close can in genetic terms be quite distant. This has implications if selecting animals for restocking and in maintaining a high genetic diversity within the population as a whole. Such issues could be identified and addressed with an improved approach to monitoring and mapping of data. For the ecology manager this type of information is essential for the determination of a strategic management approach, the sensible allocation of resources, and possible research requirements.

To produce meaningful and useful information, such a monitoring programme would need to be co-ordinated, and therefore funded, nationally. This is not the sole responsibility of the Environment Agency but should be conducted by a consortium of organisations. Survey work would be done by trained staff, giving the user more confidence in the data, and it would be carried out using agreed sampling techniques. The monitoring programme could then be repeated at an agreed interval. The benefits of such a structured monitoring programme to the large number of organisations and individuals with conservation interests would be invaluable.

\section{DATABASES}

There is a requirement for national recording of native crayfish distribution and reporting to government in fulfilment of the aims of the UK Action Plan for $A$. pallipes (THE UK BIODIVERSITY STEERING GROUP, 1995). The Environment Agency holds a large amount of data detailing crayfish distribution and seeks to keep this information updated, both for reporting the status of $A$. pallipes and assessing the threat from non-native species. However, many inconsistencies exist regarding the management of databases, some of which are outlined below:

- various means of storing data are utilised in different operational areas, including electronic databases and paper records

- some operational areas use a single database for all species while others record them separately not be recorded

- negative results (where crayfish are not found during dedicated survey) may or may

- some operational areas enter all confirmed records onto their « crayfish database » whereas others only keep survey reports from targeted work

- repetition of data exists with a number of databases holding the same information, requiring unnecessary effort in entering records.

There is a need for some means of verifying records, and for consistency in recording across different operational regions which would facilitate national reporting and make it easier to determine the status of all crayfish species. This would also benefit area offices where river catchments cross operational boundaries and where catchments within different regions are in close proximity.

Ease of data entry and easy access to records must be achieved within the Environment Agency at area level for operational reasons including the efficient provision of good quality data to external individuals and organisations. 
Recent changes in legislation mean that the Environment Agency has to address the problem of possible transfer of crayfish plague when fish are being stocked. This has resulted in the initiation of a research project, part of which is to establish the need for a national crayfish database. The Centre for Environment, Fisheries and Aquaculture Science (CEFAS) live fish movements database has been made available to Agency staff to assist in this process, and has been proposed as a suitable medium for the storage and use of crayfish records.

In addition, a means of using the National Biodiversity Network (NBN), a widely available internet information system, for obtaining and disseminating information on biodiversity species is being examined. It is proposed to look at the technical issues of linking Agency databases with the appropriate software to produce a definitive NBN database. Links with operational areas would ideally be through the NBN so that the definitive table could be held by the Agency or other lead user and links to outside organisations would be from the area databases through the NBN. Crayfish data could be held on the Agency's national freshwater invertebrate database, B4W, instead of on a separate database although this system, which is mainly used for water quality monitoring, is slow running and data retrieval is not without difficulty (although this can apparently be overcome). There is currently a $£ 25 \mathrm{k}$ research project ongoing looking at ways the Agency can link into the English Nature NBN South West Pilot Project. A £50k project has been proposed with the aim of linking B4W to the NBN.

\section{CONCLUSIONS}

There has been a significant decline in the reported distribution of $A$. pallipes across England and Wales during the period 1997-2001 compared to the preceding period 19901996 (both inclusive). This decline has been accompanied by an apparent increase in the distribution of non-native crayfish, in particular $P$. leniusculus, which is now more widely distributed than $A$. pallipes (according to presence within 10-km squares of the Ordnance Survey National Grid of England and Wales). Whether or not all new records represent actual change within the reporting period is questionable, since some post 1997 records are almost certainly due to the discovery of long-established populations. There has also been an increase in awareness and in survey quantity and quality (although this has not been consistently applied across different geographical areas) during recent years, and this is likely to have had some impact on the apparent rate of change in distribution. However these factors, which have perhaps exaggerated the real-time expansion of non-native crayfish since 1997, can only have served to produce a more accurate end-picture of crayfish distribution in England and Wales since this time.

It is not within the scope of this paper to report reasons for changes in the distribution of specific populations of $A$. pallipes. However, taking Figures 2 and 3, there are several examples of native crayfish being present in a particular $10-\mathrm{km}$ square during 1990-1996 and then absent during 1997-2001, but present in an adjacent square formerly without the species. On these occasions it would be useful to determine whether such changes are in fact the result of «pseudo-shifts " that need to be differentiated from e.g. real extinctions, and also whether errors in recording or reporting could have taken place.

Crayfish plague has certainly featured in the decline of $A$. pallipes and is known to have killed populations of the species during 1990-1996 (e.g. Wycombe/Wye catchment in Thames region in 1992 (HOLDICH and ROGERS, 1997b). Other mass mortalities are thought to have been caused by the disease (e.g. Derbyshire Derwent catchment in Midlands region from 1990 to 1993). Outbreaks of crayfish plague continue to occur 
(e.g. River Shep in Anglian region in 1999 (SLATER et al., 2001)) and will doubtless threaten $A$. pallipes in England and Wales in future years. The expansion in range of $P$. leniusculus will probably lead to more encounters between native and non-native species, with potentially damaging consequences to $A$. pallipes, even if crayfish plague is not evident (PEAY and ROGERS, 1999). This increased distribution also increases the risk of accidental spread of crayfish plague, for example during fish stocking or on contaminated fishing equipment. The recent identification of Orconectes limosus from a pond in Midlands region (P. HAYES, pers. comm.), the first record of this species from central England, is of considerable concern. The species is a vector for crayfish plague, has colonised most of the major river systems in large parts of continental Europe and could pose a serious threat to the future survival of $A$. pallipes if it were to expand its range in England and Wales (HAMR, 2002). In addition, $A$. pallipes is still vulnerable to pollution and habitat loss and these factors have certainly contributed to the continued decline of the species in certain areas since 1997.

All native crayfish populations have conservation value, but clearly some are easier to protect than others. Populations in category A catchments where non-native crayfish are absent should perhaps receive the highest level of protection, but there is also an argument for prioritising the conservation of disparate populations in order to safeguard genetic diversity (FETZNER and CRANDALL, 2002). Central and northern parts of England, where suitable geology facilitates the necessary levels of dissolved calcium in surface waters, have historically supported abundant populations of $A$. pallipes. Waters in the North East and Midlands regions still support relatively widespread populations of native crayfish and significant effort should be employed to conserve some or all of them in their historical strongholds. Key areas, whether entire regions or isolated catchments, are clearly important when considering the future of $A$. pallipes in a national, even global, context and should be prioritised or ranked by fisheries managers and conservationists in order to target available resources effectively.

A co-ordinated survey programme and regular distribution updates are required to best monitor the changing situation and to inform the development of local conservation measures and national management strategy.

Regarding the use of databases, the current situation within the Environment Agency and other organisations is less than satisfactory with much inconsistency and duplication of effort. Each area in the Agency should store data in the same format with the same survey parameters recorded, as in the B4W system. Such data should ideally then feed into a definitive database. NBN would enable exchange of information within the Agency and with external organisations without the need to copy records and hold more than one data set. This would also enable ownership and easy access of data at a local level where records can be verified. A national database, for example the CEFAS database, is necessary in the interim until the necessary technology is developed.

\section{ACKNOWLEDGEMENTS}

The catchment classification scheme is based upon work originally presented by HOLDICH and ROGERS (1997b) in their strategy for the management of $A$. pallipes. The authors are grateful to all those who supplied records and/or critical feedback on the classification update and to Martin Stark, Andrew Heaton and Shelley Howard for reviewing the draft text on behalf of the Environment Agency. Thanks are also due to David Holdich for his support and advice. 


\section{REFERENCES}

EDSMAN L., FARRIS J.S., KALLERSJO M., PRESTEGAARD T., 2002. Genetic differenciation between noble crayfish, Astacus astacus (L.), populations detected by microsatellite length variation in the rDNA ITS1 region. Bull. Fr. Pêche Piscic., 367, 691-706.

FETZNER J.W., CRANDALL K.A., 2002. Genetic Variation. In : Biology of Freshwater Crayfish, 291-326. (HOLDICH D.M., ed.). Blackwell, London.

GRANDJEAN F., SOUTY-GROSSET C., HOLDICH D.M., 1997. Mitochondrial DNA variation in four British populations of the white-clawed crayfish, Austropotamobius pallipes: implications for management. Aquatic Living Resources, 10, $121-126$.

HAMR P., 2002. Orconectes. In : Biology of Freshwater Crayfish (HOLDICH D.M., ed), 585-608. Blackwell, London.

HOLDICH D.M., ROGERS W.D., 1997a. The white-clawed crayfish, Austropotamobius pallipes, in Great Britain and Ireland with particular reference to its conservation in Great Britain. Bull. Fr. Pêche Piscic., 347, 597-616.

HOLDICH D.M., ROGERS W.D., 1997b. Strategy for the management of white-clawed crayfish (Austropotamobius pallipes) populations in England and Wales. R\&D Project Report 640, Environment Agency, Bristol.

HOLDICH D.M., ROGERS W.D., REYNOLDS J.D., 1999. Native and alien crayfish in the British Isles. In : Crayfish in Europe as alien species - how to make the best of a bad situation? (GHERARDI F. and HOLDICH D.M., Eds.), 221-235. Crustacean Issues 11. Balkema, Rotterdam.

PEAY S., ROGERS D., 1999. The peristaltic spread of signal crayfish (Pacifastacus leniusculus) in the River Wharfe, Yorkshire, England. Freshwater Crayfish, 12, 665-676.

SIBLEY P.J., 2001. Signal crayfish management in the River Wreake catchment. In : Crayfish Conference Leeds (2000) (ROGERS D. and BRICKLAND J., Eds.), 95-107. Environment Agency / International association of Astacology / English Nature.

SLATER M., ATKINSON M., ROGERS D., 2001. Environment Agency response to a crayfish mortality on the River Shep, Cambridgeshire. In : Crayfish Conference Leeds (2000) (ROGERS D. and BRICKLAND J., Eds.), 1-8. Environment Agency / International Association of Astacology / English Nature.

THE UK BIODIVERSITY STEERING GROUP, 1995. Biodiversity: The UK Steering Group Report. Vol. 2: Action Plans. White-clawed crayfish (Austropotamobius pallipes), 157-158. HMSO, London. 